\title{
Hospital Administration and its Importance in Streamlining Incident Free Health Care System Brief Outline
}

\author{
Joy deep Das Gupta \\ Director India and South Asian Countries Giostar USA 25th years in healthcare Giostar India Centre, India
}

Submission:April 03, 2018; Published: April 11, 2018

*Corresponding author: Joy deep Das Gupta, Director India and South Asian Countries Giostar USA $25^{\text {th }}$ years in healthcare Giostar India Centre, India

\section{Opinion}

Except for the birth of a child, hospital visits are more often than not unpleasant. If we have been lucky (with the patients recovery, accurate diagnosis and timely treatment and service), we look back with a sense of relief. But if it has been a disastrous experience we would rather take pleasure in spreading the good word about. That's how critical an administrator's role is in an infirmary. Much has changed in how a hospital is projected today. They are more like profit centers and require Business Head to project the right image. Hospital administration and management has indeed come of age. A hospital now hires a Healthcare Administrator/unit CEO solely for the purpose of keeping the hospital well oiled and running smoothly providing the maximum benefit to both patients and the staff.

The work of a health care management professional is therefore to completely devote him to the efficient running of the hospital or wellness centre. This effectively leaves doctors and associated staff to accomplish their work uninterrupted. The responsibilities of a health care management professional are wide ranging, necessitating multitasking. As a hospital Unit Head, administrative, human resources, supply, infrastructure and equipment management come under his /her purview. This includes a host of other responsibilities such as employing contractual services, hospital help etc. Management of medical supplies and equipment is an important aspect of the job. As an administrator, he also has a say in the policy matters of the hospital, and in collaborations and partnerships with other health services providers.
Man management people's management however, is the most important aspect of the job, since a hospital Head has to deal with in house staff and others at various levels, right from the medical staff to the governing board, including visiting dignitaries. However, this doesn't lessen the importance of gaining an understanding of finance. The hospital administrator also has to be figures savvy with the accounting processes and procedure to curtail any misappropriation of funds. The hospital HEAD's role however differs according to the size of the organization.

Smaller medical or health centre may employ a manager to handle day to day administrative work, which involves billing, maintenance, equipment supplied He may work closely with doctors, if it's a group practice and have a say in decision making. A bigger place may require the services of a UNIT HEAD in key aspects as well Business strategy, administration, work-flow plans and managing outreach programmers, seminars etc.

But every role that a health care management professional plays in the hospital is integral to his/her ability as a communicator and administrator skills which need to be honed well. Now-a-days hospital incident noticed which is mostly due to communication gap in between service providers and patient. In this context, role of hospital head / Unit head/Unit CEO is a prime mediator to resolve any issue. 
This work is licensed under Creative Commons Attribution 4.0 License DOI:10.19080/JOJPH.2018.03.555610

\section{Your next submission with Juniper Publishers} will reach you the below assets

- Quality Editorial service

- Swift Peer Review

- Reprints availability

- E-prints Service

- Manuscript Podcast for convenient understanding

- Global attainment for your research

- Manuscript accessibility in different formats ( Pdf, E-pub, Full Text, Audio)

- Unceasing customer service

Track the below URL for one-step submission https://juniperpublishers.com/online-submission.php 